\begin{tabular}{c|c} 
Journal of Business Management and & 0 \\
Economic Research & 2018, 2(11): 24-37 DOI: 10.29226/TR1001.2018.77 \\
Journal Homepage: https://www.jobmer.org &
\end{tabular}

\title{
Does Corporate Social Responsibility Improve Profitability of Banking Firms?
}

\author{
Muhammad Imran Khan \\ School of Economics, Northeast Normal University, Changchun, Jilin, China. \\ imranhaleem89@gmail.com \\ Muhammad Kamran Khan \\ School of Economics, Northeast Normal University, Changchun, Jilin, China. \\ Muhammad Rehan \\ School of Economics, Northeast Normal University, Changchun, Jilin, China. \\ Ignatius Abasimi \\ School of Economics, Northeast Normal University, Changchun, Jilin, China.
}

\begin{abstract}
This research paper examines the relationship among CSR, size, income variability, expected growth and its effect on ROA, ROE and EPS of banking firms. Panel data of the variables have been collected from the official websites \& financial reports of the selected banks for the year 2005-2017. CSR, growth and size of firm have positive \& significant effect on ROE and income variability have negative effect on ROE \& ROA. All variables have positive effect on EPS but income variability have negative effect on EPS. It is recommended that business organizations should formulate financial policies for dominating their financial position not only for the sake of profitability \& strategic objective but also giving improvement to environment, society and all stakeholders by investing in CSR practices.
\end{abstract}

Keywords: Corporate Social Responsibility (CSR), Earning per share (EPS), Return on Assets (ROA), Return on Equity (ROE), Profitability

\section{INTRODUCTION}

Corporate social responsibility (CSR) is a dynamic and modest strategy for business organizations. (Chandler \&Werther, 2013). Executives may expand competitiveness by adopting CSR strategies, based on the strengths of their corporations. (Nagurney \& Li, 2014). CSR has become a progressively significant part for companies' tasks (Deng, Kang, \&Low, 2013). Some corporations enhance their investment in corporate social responsibility while some 
firm's only show large part of their capital to present CSR activities in their annual reports. (Flammer, 2013). The last decades have observed melodramatic variations in the associations between the public, private sector and civil society. Nowadays a new idea termed as corporate social responsibility (CSR) has introduced and the primary objective of this activity is usually adopted by business in order to satisfy the needs of stakeholders engaged in cycle of business operations. (Ajala, 2005). In this modern age of business every firm and corporation examine their goodwill on the basis of social, economic, and ordinary principles. There are many debates, conflicts and contradictory views among the scholars and researchers on CSR that it helps the firms in many areas and also improve the productivity and profitability. However according to some there exists negative correlation in corporate social responsibility and firm's profit.

In the year 1950 the concept of corporate social responsibility was introduced as corporate responsibility and Howard Bowen was the first author who published a book in 1953 on corporate social responsibility. CSR is the most important and strategic part for every business organizations and corporations, that how they improve and enhance productivity of the corporations through the CSR's activities. (Srivastava, 2012). The policies employed by business concerns to conduct their business activities in such a way that is decent, civilized and beneficial to community in terms of development is known as Corporate social responsibility, (Ismail, 2009). Corporate Social Responsibility generally pronounces obligations of the firm in order to protect and improve social welfare in present as well as in the future, by creating sustainable welfares for stakeholders (Lin et al., 2009). In this modern era the strategy of CSR is an integral part of business for many organizations for addressing the environmental and social impact of company activities (Luo and Bhattacharya, 2006; Lin et al., 2009; Dabas, 2011; Beret, 2011). Although most of the corporations or firms adopt CSR policies while some of consider environment and society to be the smaller domain with the economy. (Berete, 2011). Studies show that the more the companies are socially responsible the larger the companies are profitable. (Moore, 2001).

An essay written by Milton Friedman in 1970s in New York Times about the importance of CSR in private firms for the creation of value of shareholders in the corporations. This idea was not only used but widely appreciated all over the world and also proved to be correct.. (Harjoto, 2011). Revenue is the primary object for all kind of business organizations because it is the basic component for the survival, development and long life of a business firm. All kind of business organizations and corporations have been confronted, not only by the major progressions that happened at the end of the twentieth century, such as privatization, deregulation and globalization, but also by expectations of the society from the firms regarding contributions to public welfare and social involvement. Slowly, large corporations have started to adopt the strategy of CSR processes, such as public commitments to comply with standards, fostering stakeholder involvement community investments \& conforming, systematic public reporting on environmental and social performance. Corporate Social Responsibility strategy has grown beyond, both practically and theoretically, money donations, the area of philanthropy and charity actions. CSR has become a dynamic approach to embrace the interests of stakeholders, a way to retain the modest advantage and to settle profit objectives with longterm policies. The natural value was that CSR has become an object of political actions, public debates and research study, but also a substance of supremacy in most regional and global organizations of most of the countries. Return on equity and Return on Assets are accounting ratios \& most famous measurement which are usually used by researcher that how effectively and efficiently management use the assets and equities of corporations for enhancing turnover and corporations sales to maximize productivity level. (Raza et al., 2012). The ability of a 
business or corporation to earn positive profit is termed as profitability or productivity. In this modern age of business most of the organizations paying attention on CSR because the business operate in the society and society demand some social responsibilities i.e contribution in the welfare of the society from the corporations or business organizations. The CSR is not an old topic for some countries because in Pakistan all kind of business organizations use it in the present world competition. (Islam, 2009).

The main objective of this research paper is to calculate proxy variables for commercial banks of Pakistan and effect of CSR on the profitability of commercial banks in Pakistan.

\section{REVIEW OF LITERATURE}

The literature regarding CSR is rich with hundreds of research studies, exploring the relationship among business, financial performance, profitability and social activities of the corporations y (e.g. Griffin and Mahon, 1997; Waddock and Graves, 1997; Jackson and Parsa, 2009; Kempf and Osthoff, 2007). But according to quantitative research studies it is concluded that there are unsettled proofs of the relationship between profitability and CSR. Published Literature is available on the topic of CSR and its relation with profitability of corporations ; effect of corporate social responsibility on profitability of banking firm, corporations and businesses of various countries of the world .Important published literature on the topic of CSR and profitability of business organizations is summarized as under:

Aupperle et al. (1985) state in their study that there is negative relation among profitability, productivity, financial performance of corporation or business organization and CSR activities. Further this research study states that by investing on CSR activities the cost of the those firms increase that are not socially responsive and also it is a financial burden and weak the position of business. The researchers Pava and Krausz (1996) conducted research study by examining about twenty one research studies on CSR and Profitability between the year 1972s and 1992s. The results of twelve studies showed positive relation 8 showed no relation and 1 study showed inverse relationship among CSR and financial performance.

Waddock and Graves (1997) measure the profitability of corporate financial performance by using three measures which are ROA, ROE, and ROS and other numerous procedures for measuring profitability of corporations for the business stakeholders. Business organization with good financial position can invest in long term project by investing or building education institute for the welfare of the society while firm having weak financial position will adopt traditional CSR activities. Carroll (1999) conducted research study on the topic of CSR wherein he concluded that the term CSR is social responsibility of the firm. Many people have defined CSR according to their own research and concepts but the most citied and accurate definition is given by Carroll (1979) "the social responsibility of firms involves the ethical, economic, legal and discretionary hopes that society has of organizations at the any given point in time'. He further states that firm carried these responsibilities for the sake of both the firm at large and the society. So, firms are indebted to take the interest of the society into consideration when taking its verdict because at last the society is greatly pretentious by those verdicts. Different economists and researchers worked on this topic and give their views which are different from each other. Conflict over CSR exists among different researcher and scholars from the year 1950s.

A researcher of UK, Moore (2001) conducted research study on the topic of CSR, profitability and productivity, by investigating the association among these components. The results of his study showed negative relation among the productivity, profitability and CSR activities of supermarket industry in UK. However according to another researchers, Mc Williams and Siegel (2001) states in their study that there is no significant relation among corporate 
performance and CSR activities. According to the research study results of " (Wild et al, 2005) the good performance of the business totally depends on its maximum return on assets. It reflects the stable position of the company and attract investors. The ability of the company to meet its liabilities of short term period is usually calculated through liquidity ratio. However performance of the managers that how efficiently they use or manage assets measured through asset management ratio. (Brigham and Houston, 2001) while the ability of firms to manage its long period obligations measured through Debt Management Ratio.

According to Van de Ven and Graafland (2006) stated in his study that CSR has positive effect on the profitability of the corporations. According to the study of Peloza and Papania (2008) the profitability aspect of different organizations belong to dissimilar industry may different in CSR effect and it also depends that how much level of significance allotted to each main stakeholders for the industry. Inoue and Lee (2011) conducted study in order to know that how different extents of CSR activities could affect financial performance of firms within 4 similar tourism industries. The results of their study showed that financial impact different across these four same tourism industries. According to Godfrey et al. (2009) that if management of corporation adopt both CSR and profitability strategy then CSR and financial performance will be perfect.

Raza et al. Used the quantitative data for analysis from the year 1972 to 2012. In this study they select Stock market return, Return on equity (ROE), Return on asset (ROA), Earning per share (EPS) and Return on sale for their analysis. Result of their study showed that these accounting ratios are very perfect for ascertaining the profitability of the firms and almost all researchers rely on these accounting ratios i.e. EPS, ROA, ROE and ROS for their analysis. According to a study conducted by Rahmawati (2014) on Indonesian stock market for ascertaining the association among CSR and investment activities and its effect on firms maximizing profit activities. In this study he analyzed 27 organizations data for the year 2006-2008 and concluded that there is direct association of CSR with financial performance, competitive edge and market share of corporations. Shruti (2014) conducted research for the purpose to know the association among the CSR, investment and profitability of the firms. Author conducted this research on UK's three industries by taking data from 2008-12 of ROA and ROE for calculating financial performance and profitability of these industries i.e. Petroleum, Gas and extraction industry. In this study the author concluded that CSR, Investment, Financial performance have significant effect.

According to a study conducted by Abdullah (2014) on stock exchange of Pakistan for the purpose to know about the effect of investment in CSR and its relation with profitability of the firm. In this study the author took the data of 20 companies out of which half were practicing investment in CSR and the remaining were not engaged in the said activities. After analyzing the data the results of the study showed that those firms which were engaged in the practicing of investment in social welfare of the workers or stakeholders and CSR were financially strong and earned maximum profit as compared to the firm which were not engaged in such practices.

\section{RESEARCH METHODOLOGY}

This section of our paper discuss about the Dependent, independent and control variables, population, sample, sampling technique, data collection, different tests, statistical software and model of the study.

\section{Population, size, Data and sampling technique.}

The study population consists the following ten banks operating in Pakistan. Standard chartered Bank, Bank of Punjab, Askari Bank, MCB bank, United Bank, Bank Alfalah, Habib 
Bank, Allied Bank, Faysal Bank and Bank Al-Habib. Data is collected from the annual reports available on the official website of these banks as well State Bank of Pakistan. In this research study we have used data of 13 years from 2005-2017, in this research study we have used non probability sampling technique.

\section{Variables for the Study}

We have used three kinds of variables in our research paper.

Independent variables

Dependent variables

Control variables.

\section{Independent Variable}

In this research paper Corporate Social Responsibility is taken as Independent variable because it is not dependent on any other variable in this research study. .

\section{MEASURING CORPORATE SOCIAL RESPONSIBILITY (CSR)}

Basically there are two proxies which are mostly adopted by researcher for the measurement of Corporate Social Responsibility i.e donations and money spent on for the welfare of the firm's workers. Coffey \& Fryxell and 1991, Lin, et al., 2009. In many research study it has analyzed that most of the organizations consumer their millions amount on the charitable activities which indicates that donation is used as a proxy for the measurement of CSR. Compensation to workers in the firms is also used as proxy for CSR. (Muller \& Kolk, 2008). In most of the research work the researchers have used these proxies for measuring CSR. We will also use these as proxy for CSR in our research study. (Cox et al, 2004 Scholtens, 2008, and Muller \& Kolk, 2008) CSR = Donation + Worker's welfare funds / Earning before tax.

\section{Dependent Variables}

In our this research study we have taken Earing per share (EPS), Return on Asset (ROA) and Return on Equity (ROE) as our dependent variables which are accounting ratio, usually used by researchers and chartered accountants for calculation of profitability of the firms.

\section{Control Variables}

In this research study we have taken income Variability, Size of Firm and Expected Growth rate our control variables.

\section{Size of Commercial Banks}

Large type of business organization and firm usually can safe their organization from losses due to their policies and according to the static trade off hypothesis an organization would be more diversified if the size of such organization is large and it will be in a position to protect itself against loss in some cases. Numerous techniques are adopted by the researcher for the calculation of firm size one of the most important procedure is total number of employees and total assets and natural log of the firm's total assets.

$$
\text { Size }=\text { Log total assets }
$$

\section{Expected Growth}

The growth of the firms can be calculated as growth is equal to current year total assets divided by previous year total assets multiply with one hundred. Growth is very important component 
for all type of organization because the firm size depends on its annual growth. The famous formula for calculating growth is as follows.

Growth $=\frac{\text { total assets of current year }}{\text { total assets of previous year }} \times 100$

\section{Income Variability}

It effect the profitability of firm and used for measuring risk as bankruptcy increase. It can be calculated as under. (Erica et al., 2011)

$$
\text { Income variability }=\frac{\text { STDEV of EBIT }}{\text { Total Assets }}
$$

\section{Model for the Study}

In our this research study profitability is dependent variable for which ROA, ROE and EPS have used as proxy dependent variables, CSR is independent variable while Growth, Size and income variability has used as control variable in this research study. The below model is developed for this study.

ROA $_{i t}=\alpha+\beta 0 C S R_{i t}+\beta 1$ firm size $_{i t}+\beta 2$ expected growth git $+\beta 3$ firm income variability ${ }_{i t}+\varepsilon$

$R O E_{i t}=\propto+\beta 0 C S R_{i t}+\beta 1$ firm Sizeit $+\beta 2$ expected growth fit $+\beta 3$ firm income variability $_{i t}+\varepsilon$

$E P S_{i t}=\alpha+\beta 0 C S R_{i t}+\beta 1$ firm Size $_{i t}+\beta 2$ expected growth $i t+\beta 3$ firm income variability $_{i t}+\varepsilon$

\section{RESULTS AND DISCUSSION}

In this section of our research paper we have analyzed the data regarding dependent, independent and control variables through statistical software. The results of descriptive statistics, chow test, Hausman test and Breusch Pagan LM are interpreted below in details:-

\subsection{Descriptive Statistics}

\begin{tabular}{|c|c|c|c|c|c|}
\hline Variables & Observations & Mean & $\begin{array}{c}\text { Std } \\
\text { Deviation }\end{array}$ & Minimum & Maximum \\
\hline ROE & 130 & 25.26 & 6.54 & 17.34 & 23.8 \\
\hline ROA & 130 & 3.95 & 2.66 & .5 & 5.84 \\
\hline EPSRS & 130 & 9.83 & 4.45 & 3.05 & 22.07 \\
\hline SIZE & 130 & 11.09 & 4.66 & 19 & 29 \\
\hline $\begin{array}{l}\text { Expected } \\
\text { Growth }\end{array}$ & 130 & 121.27 & 27.11 & 1.654 & 140.20 \\
\hline Income & 130 & .0333 & 0.005 & 0.221 & 0.433 \\
\hline CSR & 130 & 2.26 & 8.77 & 4.97 & 127.34 \\
\hline
\end{tabular}

According to the results of descriptive statistics there are 130 observations for every variable. The mean value for ROE is 25.26, standard deviation value 6.54, minimum value $17.343 \&$ maximum value 21.6. The mean value of ROA is 3.95, SD 2.66, minimum value 0.5 and 
maximum value 5.84. Mean value for EPS is 9.83 , SD 4.45, minimum value 3.05 and maximum value 22.07. Size of firm's mean value 11.09, SD 4.66, minimum value $19 \&$ maximum value 29. Expected growth of firm has a mean value of 121.27, SD 27.11, minimum value 1.654 and maximum value 140.20 . Income variability mean value is 0.333 , SD 0.005 , minimum value 0.221 and maximum value of 0.433 and CSR mean value 2.26,SD 8.77, minimum value 4.97 and maximum value 127.34.

\subsection{Model for ROA}

\begin{tabular}{|c|c|c|c|}
\hline Test & Null hypothesis & Alternate Hypothesis & P value \\
\hline Chow & Pooled OLS is better than & FE Model is better than & 0.5527 \\
FP & Pooled OLS is better than RE & PE Model is better than & \multirow{2}{*}{0.4267} \\
Model & Pooled OLS & \\
\hline \multirow{2}{*}{ Hausman } & REM is better than FEM & FE Model is better than RE & 0.2857 \\
& & Model & \\
\hline
\end{tabular}

\section{Model Selection for ROA}

\section{Chow Test for ROA}

The main objective of this test to select best model between FEM and pooled OLS. The P value is .5527 which states that pooled OLS is better than FEM.

\section{Breusch Pagan Lm Test for ROA}

This test is used for selection between random effect model and pooled regression and random effect model. The $\mathrm{p}$ value is 0.4267 which is greater than 0.05 . Therefore pooled OLS is better model.

\section{Haussmann Test for ROA}

The Haussmann test is used to select an appropriate model between random and fixed effect model. The $p$ value is 0.2857 which is greater than 0.05 which states that random effect model is better for this study.

\subsection{Model for ROE}

\begin{tabular}{|c|r|r|r|}
\hline Test & Null Hypothesis & Alternate Hypothesis & P value \\
\hline \multirow{2}{*}{ Chow } & PooledOLS is better than & FEModel is better than & 0.0371 \\
& FEModel & PooledOLS & 0.0268 \\
BP & PooledOLS is better than & REModel is better than & \\
REModel & PooledOLS & 0.4532 \\
\hline \multirow{2}{*}{ Hausman } & REModel is better than & FEModel is better than & \\
\hline
\end{tabular}




\section{Model for ROE}

\section{Chow Test for ROE}

The main objective of this test is to decide whether to select OLS or FEM. The P value is 0.0371 which is less than 0.05 so fixed effect model is better for this study.

\section{Breusch and Pagan LM Test for ROE}

This test is used for selection between OLS and random effect model. The P value is 0.0268 which is less than 0.05 so random effect model is appropriate model than pooled regression model for this study.

\section{Haussmann Test for ROE}

This test is usually use to select between Fixed effect model or Random Effect Model. The P value is 0.4532 which is greater than 0.05 so random effect model is better than FEM for this study.

\subsection{Model for EPS}

\begin{tabular}{|c|c|c|c|}
\hline Test & Null hypothesis & Alternate Hypothesis & P value \\
\hline Chow & $\begin{array}{l}\text { Pooled OLS is better than } \\
\text { Fixed EM }\end{array}$ & $\begin{array}{c}\text { Fixed EM is better than } \\
\text { Pooled OLS }\end{array}$ & 0.0376 \\
\hline $\mathrm{BP}$ & $\begin{array}{l}\text { Pooled OLS is better than } \\
\text { REM }\end{array}$ & $\begin{array}{c}\text { REM is better than Pooled } \\
\text { OLS }\end{array}$ & 0.0384 \\
\hline Hausmann & $\begin{array}{c}\text { Random EM is better than } \\
\text { Fixed EM }\end{array}$ & $\begin{array}{c}\text { Fixed EM is better than } \\
\text { Random EM }\end{array}$ & 0.8740 \\
\hline
\end{tabular}

\section{Model for EPS}

\section{Chow test for EPS}

Chow test for EPS shows the P value 0.0376 which is less than 0.05 so Fixed Effect Model is better than Pooled OLS..

\section{Breusch Pagan LM Test for EPS}

This test is used to select between random effect model and pooled regression. The P value is 0.0384 which is less than 0.05 so REM is better than pooled regression model.

\section{Hausman Test for EPS}

This test is used to select between FEM and REM. The P value is 0.8740 which is greater than 0.05 so random effect model is better than FEM for this study. 


\subsection{Table for Multi Co-Linearity}

\begin{tabular}{|c|c|}
\hline Variables & VIF \\
\hline Size & 1.75 \\
\hline CSR & 1.92 \\
\hline Income & 1.36 \\
\hline Expected Growth & 1.34 \\
\hline Mean VIF & 1.64 \\
\hline
\end{tabular}

The value of all the explanatory variables VIF is less than 10 which states that there is no multi co-linearity problem in the data of this research study because variance inflation factor (VIF) is very important tool for decision.

\subsection{Table for Random Effect Results for ROE}

\begin{tabular}{|c|c|c|c|c|}
\hline Variables & Coefficients & Standard Error & T value & P value \\
\hline Size & 0.91 & 0.41 & 2.24 & 0.0457 \\
\hline $\begin{array}{c}\text { Expected } \\
\text { Growth }\end{array}$ & 0.82 & 0.12 & 7.06 & 0.000 \\
\hline $\begin{array}{c}\text { Income } \\
\text { Variability }\end{array}$ & -0.61 & 0.34 & -1.82 & 0.052 \\
\hline CSR & 0.91 & 0.21 & 4.4 & 0.021 \\
\hline Constant & 16.23 & 17.12 & 0.92 & 0.333 \\
\hline
\end{tabular}

The table of Random Effect Model for ROE shows that size, expected growth and CSR of firm have positive relation with ROE and the other variables have negative relations with ROE. The coefficient in the table indicates that one unit change in size will change ROE by 0.91 units positively and the coefficient of one unit increase in expected growth will increase ROE by 0.82 units. However income variability have negative relation with ROE. The results of our study are in line with the results of Basu, (2008) and also a similar results have s been drawn by Harmony J. Palmer (2012). From the above results it is concluded that CSR, growth and size of firm have significant effect on ROE. 
4.7. Table for Pooled OLS Model for ROA

\begin{tabular}{|c|c|c|c|c|}
\hline Variables & Coefficients & Standard Error & T value & P value \\
\hline Size & 0.302 & 0.12 & 2.05 & 0.050 \\
\hline $\begin{array}{c}\text { Expected } \\
\text { Growth }\end{array}$ & 0.19 & 0.76 & 0.303 & 0.692 \\
\hline $\begin{array}{c}\text { Income } \\
\text { Variability }\end{array}$ & -3.64 & 2.55 & -1.5 & 0.128 \\
\hline CSR & 0.44 & 0.16 & 2.2 & 0.046 \\
\hline Constant & -5.63 & 3.33 & -1.38 & 0.251 \\
\hline
\end{tabular}

The results of pooled OLS for ROA shows that CSR, size and growth of firm have positive relation with ROA while income variability have negative effect on ROA. CSR and Size of firm have significant effect on ROA while other variables have insignificant effect on ROA. The results of this study are same with the results of Basu, (2008).

\subsection{Table Random Effect Model for EPS}

\begin{tabular}{|c|c|c|c|c|}
\hline Variables & Coefficients & Standard Error & T value & P value \\
\hline Size & 0.72 & 0.32 & 2.76 & 0.052 \\
\hline Expected Growth & 0.92 & 0.34 & 3.34 & 0.022 \\
\hline Income Variability & -0.67 & 0.40 & -1.5 & 0.636 \\
\hline CSR & 0.50 & 0.14 & 3.5 & 0.034 \\
\hline Constant & 0.72 & 0.69 & 1.66 & 0.346 \\
\hline
\end{tabular}

According to random effect model for EPS all variables have positive effect on EPS but expected income variability of firm have negative effect on EPS. Furthermore according to this table results CSR, growth and size have significant effect on EPS at $5 \%$. The result of this study is in line with the previous results of basu, (2008) \& Harmony J. Palmer (2012).

\section{SUMMARY, CONCLUSIONS AND RECOMMENDATIONS}

This research paper investigated about the association among CSR, Size of firm, income variability, expected growth earning and Performance of the selected commercial banking firms. ROA, ROE and EPS are used as proxies of the performance of firms in this study. ROA, ROE and EPS are used as dependent while CSR as independent variable while Size of firm, income variability and expected growth earnings are used as control variables in this study. Data from 2005-2017 was collected from the websites of the selected firms and state bank CSR, growth and size of firm have positive \& significant effect on ROE and income variability have negative effect on ROE and ROA. All variables have positive effect on Earing Per Share but expected income variability of firms have negative effect on EPS.

The Policy makers of the business organizations should implement CSR strategy both for the sake of organization as well as for the welfare of the society. The firm should also increase its 
level of productivity and profitability through CSR strategies so that the all kind of stakeholder may be protected from social as well as financial loss.

This study also suggest that firms mainly working on large scale or corporations should pay attention \& should maintain proper head in their budget for the CSR so that the strategies of the said may be implement easily.

It is recommended that business organizations should formulate financial policies for dominating their financial position not only for the sake of profitability \& strategic objective but also giving improvement to environment, society and all stakeholders by investing in CSR practices.

\section{References}

A.B. Carroll,. (1979): A Three-Dimensional Conceptual Model of Corporate Social Performance,' Academy of Management Review, 4, 4: 497-505.

Ajala, V.O. (2005). Public Relations: in search of professional excellence. 2nd edition, MayBest Nigeria Limited Ibadan, 203-204.

Ajala, V.O. (2005). Public Relations: in search of professional excellence. 2nd edition, MayBest Nigeria Limited Ibadan, 203-204.

Allied Bank Limited. (2011-2013). Annual Reports available at website of Allied Bank Limited, Retrieved on March 10, 2015 from www.abl.com

Arooj Abdullah (2014): European Journal of Business and Management ISSN 2222-1905 (Paper) ISSN 2222-2839 (Online) Vol.6, No.31.

Aupperle, K. E., Carroll, A. B., and Hatfield, J. D. Hatfield. (1985). An Empirical Examination of the Relationship between Corporate Social Responsibility and Profitability. The Academy of Management Journal, 28(2), 446-463

Bank Alfalah. (2011-2013). Annual Reports available at website of Bank Alfalah, Retrieved on March 8, 2015 from www.bankalfalah.com,

Basu, K. \& Palazzo, G. (2008). Corporate Social Responsibility: A Process Model of Sensemaking. Academy of Management Review, 33, 122-136.

Berete, M. (2011). Relationship between Corporate Social Responsibility and Financial Performance in the Pharmaceutical Industry, Unpublished Ph.D. dissertation, Walden University.

Brigham, Eugene F., and Houston Joel F, (2001), Financial Management, Translation by Erlangga Publishing Team. Eight Edition, II Book. Erlangga Publishing, Jakarta.

Carroll, A.B. (1991). The pyramid of corporate social responsibility: toward the moral management of organizational stakeholders. Business Horizons, 34(4), 39-48.

Carroll, A.B. (1999). Corporate social responsibility: evolution of a definitional construct. Business and Society, 38, pp. 268-295.

Chandler, D. B., \& Werther, W. B. (2013). Strategic CSR: Stakeholders, globalization, and sustainable value creation. Thousand Oaks, CA: Sage Publications. 
Coffey, B.S. and G.E. Fryxell,(1991) Institutional ownership of stock and dimensions of corporate social performance: An empirical examination. Journal of business ethics, 10(6): p. 437-444.

Cox, P., S. Brammer, and A. Millington, (2004): An empirical examination of institutional investor preferences for corporate social performance. Journal of business ethics, 52(1): p. $27-4$..

Dabas, C.S. (2011). Doing well by doing good or doing smart? antecedents and outcomes of corporate social performance, Unpublished Ph.D. dissertation, Michigan State University.

Deng, X., Kang, J. K., \& Low, B. S. (2013). CSR and stakeholder value maximization: Evidence from mergers. Journal of Financial Economics, 110(1), 87-109. doi:10.1016/j. jfineco.2013.04.014.

Erica, Y., and V. Chris (2011): Corporate Social Responsibility Reporting and Earnings Management: The Role of Political Costs. Australasian Accounting, Business and Finance Journal, 55(5)..

Flammer, C. (2013). Corporate social responsibility and shareholder reaction: The environmental awareness of investors. Academy of Management Journal, 56, 758- 781.

Flammer, C. (2015). Does product market competition foster CSR? Evidence from trade liberalization. Strategic Management Journal, 36, 1469-1485.

Friedman, M. (1970). The Social Responsibility of Business Is to Increase Its Profits. New York Times Magazine

Godfrey, Paul, Craig Merrill, and Jared Hansen (2009). The Relationship Between Corporate Social Responsibility and Shareholder Value: An Empirical Test of the Risk Management Hypothesis. Strategic Management Journal 30(4): 425-445.

Graafland, J., \& Van, B. (2006). Strategic and moral motivation for corporate social responsibility. Journal of Corporate Citizenship, 22, 111-23.

Griffin, J.J., \& Mahon, J.F. (1997). The Corporate Social Performance and Corporate Financial Performance Debate Twenty-five Years of Incomparable Research. Business and Society, $36(1), 5-31$.

Habib Bank. (2011-2013). Annual Reports available at website of Habib Bank, Retrieved on March 9, 2015 from www.hbl.com

Habib Bank. (2011-2013). Annual Reports available at website of Habib Bank, Retrieved on March 9, 2015 from www.hbl.com

Harmony J. Palmer (2012) Corporate Social Responsibility and Financial Performance: Does it pay to Be Good? CMC Senior Theses. Paper 529.

Inoue, Y., and Lee, S. (2011), 'Effects of different dimensions of corporate social responsibility on corporate financial performance in tourism-related industries', Tourism Management, Vol 32, No 4, pp 790-804.

Ismail, M. (2009).Corporate social responsibility and its role in community development: an international perspective, The Journal of International Social Research, Vol. (2/9) Fall.

Jackson, L. A., and H. G. Parsa. (2009). Corporate social responsibility and financial performance: A typology for service industries. International Journal of Business Insights and Transformation 2:13-21. 
Jo, H., \& Harjoto, M.A. (2011). Corporate governance and firm value: The impact of Corporate Social Responsibility. Journal of Business Ethics, 103, 351-383.

Kempf, A., and P. Osthoff (2007): "The Effect of Socially Responsible Investing on Portfolio Performance," European Financial Management, 13(5), 908-922.

Lin, C. H., Yang, H. L., and Liou, D. Y. (2009). The impact of corporate social responsibility on financial performance: Evidence from business in Taiwan, Technology in Society, Vol. 31, No. 1, pp. 56-63.

Lin, C.H., H.L. Yang, and D.Y. Liou,(2009): The impact of corporate social responsibility on financial performance: Evidence from business in Taiwan. Technology in Society, 31(1): p. 56-63.

Luo, X., \& Bhattacharya, C. . (2006). Corporate Social Responsibility, Customer Satisfaction, and Market Value. Journal of Marketing, 70(4), 1-18. doi:10.1509/jmkg.70.4.1

Moore, G. (2001). Corporate social and financial performance: An investigation in the U.K. supermarket industry. Journal of Business Ethics, Vol. 34, No. 3/4, pp. 299-315.

Muller, A. and A. Kolk (2010): Extrinsic and intrinsic drivers of corporate social performance: evidence from foreign and domestic firms in Mexico. Journal of Management Studies, 47(1): p. $1-26$.

Muller, A., Kolk, A. 2008. CSR performance in emerging markets. Evidence from Mexico. Journal of Business Ethics, DOI 10.1007/s10551-008-9735.

Muslim Commercial Bank. (2011-2013). Annual Reports available at website of Muslim Commercial Bank, Retrieved on March 8, 2015 from www.MCB BANK Bank.com.pk

Nagurney, A., \& Li, D. (2014). A dynamic network oligopoly model with transportation costs, product differentiation, and quality competition. Computational Economics, 44, 201-229. doi:10.1007/s10614-013-9387-6.

Pava, M. \& Krausz, J. (1996). The association between corporate social-responsibility and financial performance: The paradox of social cost. Journal of Business Ethics, 15(3), 321357.

Pava, M.L. (2008). Why corporations should not abandon social responsibility. Journal of Business Ethics, 83(4), 805-812.

Peloza, J., \& Papania, L. (2008). The missing link between corporate social responsibility and financial performance: Stakeholder salience and identification. Corporate Reputation Review, 11: 169-181.

Rahmawati, Honggowati, S., Supriyono, E. (2014), The effect of corporate social responsibility on financial performance with real manipulation as a moderating variable. International Journal of Management, Economics and Social Sciences, 3(2), 59-78.

Rainey, D.L. (2006). Sustainable business development: inventing the future through strategy innovation, and leadership. Cambridge University Press Cambridge.

Raza, A.; Ilyas, M.I.; Rauf, R.; Qamar, R. (2012): Relationship between Corporate Social Responsibility (CSR) and Corporate Financial Performance (CFP): Literature review approach. Elixir Financ. Manag., 46, 8404-8409. 
Raza, S. A., Jawaid, S. T., \& Shafqat, J. (2012). Profitability of the Banking Sector of Pakistan: Panel Responsibility on Financial Performance of Corporations: Evidence from Pakistan. International Journal of Learning and Development, 2(6).

Scholtens, B. (2008). A note on the interaction between corporate social responsibility and financial performance. Ecological Economics, 68(1), 46-55.

Scholtens, B. (2008): A note on the interaction between Corporate Social Responsibility and financial performance. Ecol. Econ. 68, 46-55

Shruti Singh (2014), University of Twente PostBox 217, 7500AE Enschede, The Netherlands Journal.

Siegel, D. (2001). 'Do British companies really need a minister to make them socially responsible?'. Parliamentary Brief, 7, 7-8, Special Supplement on Business and the Community.

Srivastava, A., Negi, G., Mishra, V. \& Pandey, S. (2012). Corporate social responsibility: a case study of TATA group. Journal of Business and Management, 3(5), 17-27.

Surroca, J., Tribó, J.A., \& Waddock, S. (2009). Corporate responsibility and financial performance: the role of intangible resources. Strategic Management Journal, 31(5), 463490.

United Bank Limited. (2011-2013). Annual Reports available at website of United Bank, Retrieved on March 9, 2015 from www.ubldirect.com.pk

Waddock, S.A., Graves, S.B. (1997). The Corporate Social Performance-Financial Performance Link. Strategic Management Journal, 8(4), 303-319.

Wild, Subramanyam, and Halsey. (2005). Financial Report Analysis. Eight Edition. Translated by: Yanivi S. Bachtiar and S. Nurwahyu Harahap. Salemba Empat. Jakarta. 